\title{
Relative Competitiveness between Industrial Tomato and Slender
}

\section{Amaranth}

\author{
B. P. Silva ${ }^{1}$, P. L. C. A. Alves ${ }^{1} \&$ M. P. Nepomuceno ${ }^{1}$ \\ ${ }^{1}$ FCAV/São Paulo State University, Jaboticabal, SP, Brazil \\ Correspondence: B. P. Silva, FCAV/São Paulo State University, Jaboticabal, SP, Brazil. Tel: 55-16-9206-1105. \\ E-mail: brunapiresagro@yahoo.com.br
}

\author{
Received: January 25, 2013 Accepted: February 19, 2013 Online Published: March 15, 2013 \\ doi:10.5539/jas.v5n4p103 URL: http://dx.doi.org/10.5539/jas.v5n4p103
}

\begin{abstract}
The industrial tomato (Solanum lycopersicum) is subject to weed interference that depends, among other factors, on plant density. This work aimed to quantify the competitive interactions and competitive indexes between industrial tomato and slender amaranth (Amaranthus viridis L.). An additive experiment for the two monocultures (pure stands) that varied from 20 to 100 plants $\mathrm{m}^{-2}$ was used to determine the value at which the production of each species became independent of the density. A replacement series experiment was also used, with a total density of 60 plants $\mathrm{m}^{-2}$ and five intercropping ratios (tomato: slender amaranth with 100:0, 75:25, 50:50, 25:75 and 0:100 ratio), both experiments used a completely randomized with four replications. Regression and coefficient of competitiveness analyses were performed. Tomato showed a higher competitive ability for resources than slender amaranth, and the intraspecific competition was more important than interspecific competition for the industrial tomato.
\end{abstract}

Keywords: Lycopersicon esculentum, Solanum lycopersicum, Amaranthus viridis, interference, replacement series

\section{Introduction}

Tomato (Solanum lycopersicum) is one of the most important crops in the world, with the worldwide production in 2009 being more than 151 million tonnes, including a cultivated area of more than 4 million hectares. China, the United States and India are the biggest producers of tomatoes. In Brazil, the ninth largest producer, tomato is one of the most important commercial horticultural crops, with an annual production of 4.1 million tonnes in an area of approximately $65,000 \mathrm{ha}$, with an average productivity of $63 \mathrm{t} \mathrm{ha}^{-1}$ (Agrianual, 2012).

However, similar to other crops, tomatoes are subject to losses in productivity due to ecological factors, particularly weed interference. Weeds are responsible for productivity losses due to both direct and indirect effects: directly, by competing for environmental resources (light, water, nutrients, space and $\mathrm{CO}_{2}$ ), and indirectly, by acting as hosts of insect disease vectors and influencing the operation efficiency of the harvest.

The emergence of weeds in tomato crops throughout the entire lifecycle is favored mainly by the architecture of the canopy and row spacing (Nascente et al., 2004). Weeds change the growth and development of tomatoes, causing reduction in the quantity, size and weight of the produced fruits, and may also interfere with fruit maturation and increase the amount of rotten fruits, depending on the duration of coexistence (Hernandez et al., 2007).

Slender amaranth (Amaranthus viridis L.) is one of the main species that affects the development of tomato plants. This species has a high potential to interfere with agricultural crops due to its efficient use of resources during the early stages of growth (Carvalho et al., 2008).

Evaluating the interference of weeds in tomato, Silva et al. (2010) found that slender amaranth accumulated more dry matter and grew better than purple nutsedge (Cyperus rotundus), hairy beggarticks (Bidens pilosa) and American black nightshade (Solanum americanum), demonstrating the greatest potential interference. Furthermore, slender amaranth, along with American black nightshade, reduced the production of tomato fruits and was the species that most negatively affected the accumulation of nutrients in the tomatoes.

Plant density is a major factor to the weed community in culture: the greater the density of the weeds, the greater is the number of individuals competing for the same resources, and the competition suffered by the cultured 
plants is more intense (Pitelli \& Karam, 1988). Furthermore, plant density is an important management factor that influences the yield of crops (López-Bellido et al., 2005; Dong et al., 2010; Ciampitti \& Vyn, 2011). The crop yield per unit area responds to plant density in a curvilinear mode, with the maximum yield occurring at the optimum plant density, which depends upon the crop species, environmental conditions and agronomic factors (Hiltbrunner et al., 2007; Dong et al., 2010; Ciampitti \& Vyn, 2011). As plant densities are decreased, the reduction in the number of plants per unit area is partially compensated by an accompanying increase in the productivity of each plant.

Replacement series (Harper, 1977; Wit, 1960) are often employed for the study of weed competition, especially when considering the effect of density and the ratio of the plants. This type of experimental design is based on a constant total plant density in the potted culture and a variable proportion of the two species or biotypes in competition (Harper, 1977). Isolated populations of the examined species, called monocultures, are also included in the experiment at the same density. The basic principle of this experimental design is to determine the yield of mixed competing species and to compare it with the yield of the monocultures. The assumption is that the total pot density is sufficient to capture all of the resources available for growth considering the "constant final yield law". In these studies, the dry mass production and leaf area are basic variables that are evaluated when studying plant growth (Radosevich, 1987).

The present study aims to quantify the relative competitiveness between industrial tomato and slender amaranth by measuring the effects of the density and proportion of the plants.

\section{Materials and Methods}

Two experiments were conducted, additive monocultures (tomato and slender amaranth) and replacement series, in an area located in Jaboticabal, state of Sao Paulo, Brazil $\left(21^{\circ} 15^{\prime} 22^{\prime \prime} \mathrm{S}, 48^{\circ} 18^{\prime} 58^{\prime \prime} \mathrm{W}\right.$ and an elevation of 595 $\mathrm{m})$, from January to September of 2011.

The first experiment consisted of additive monocultures containing only treatments with each species at equivalent densities $\left(20,40,60,80\right.$ and 100 plants $\left.\mathrm{m}^{-2}\right)$ for the determination of the threshold density, above which the productivity for both species does not increase. This density was used in the second experiment, a replacement series, in which the two species coexisted in different proportions of tomato plants: slender amaranth (100:0, 75:25, 50:50, 25: 75 and 0:100).

The experiments were conducted in pots of fiber cement, with a capacity of 108 liters (area $0.36 \mathrm{~m}^{2}$ ) filled with a typical Oxisol. Tomato (HEINZ 9553) and slender amaranth (Amaranthus viridis) seeds were sown in polystyrene trays of 128 cells filled with horticultural substrate $\left(\operatorname{Plantmax}^{\circledR}\right)$, and the seedlings were transplanted to the pots described above.

The experimental design for the two experiments consisted of randomized blocks, with five treatments and four replicates.

The evaluations of the monocultures and replacement series were performed at 60 days after transplanting by measuring the height, number of leaves, flowers and fruits, fruit fresh mass, dry mass of the leaves, stems and fruits and total mass for the tomato plants. Meanwhile, for the slender amaranth plants the height, leaf number, dry mass of the leaves, stems and inflorescences and the total mass were measured. The dry mass of each species was obtained by drying the plants in a forced-air oven at $70^{\circ} \mathrm{C}$; the leaf area of these plants was obtained using the LiCor 3000A device.

The data obtained in the additive monoculture experiment were analyzed using nonlinear regression. The characteristics of the two species affected by the interference among the individuals were then represented graphically by including the values expressed by the plants as compared to the density of 20 plants. $\mathrm{m}^{-2}$ (lowest density). Therefore, the density values of 20 plants $\mathrm{m}^{-2}$ was considered as the reference (100\%), and all of the other absolute values obtained for other densities were calculated from the values of the lower density. A linear regression analysis was performed using the reciprocal of the dry mass of the shoots (DMS: leaves + stems) as the dependent variable (1/DMS) and the reciprocal of the density as the independent variable (1/D).

The data for the reciprocal of the dry mass of the shoots produced by the plant population per square meter were subjected to regression analysis using the sigmoidal model of Boltzman: $\left[\mathrm{Y}=(\mathrm{A} 1-\mathrm{A} 2) /\left(1+\mathrm{e}^{\wedge}((\mathrm{x}-\mathrm{x} 0) / \mathrm{dx})\right)+\mathrm{A} 2\right]$, where $\mathrm{A} 1=$ the minimum production of dry mass, $\mathrm{A} 2=$ the maximum production, $\mathrm{x}=$ the population size, $\mathrm{dx}=$ the speed of the species increase with increasing density and $\mathrm{x} 0=$ the coefficient $\mathrm{Kn}$. In this regression function, the theoretical maximum production (Ymax) was determined, and the population that is reached at a production of $50 \%$, the coefficient $\mathrm{Kn}$, determines the sensitivity of the species to the competition among the individuals. Following the procedure proposed by Wit and Van Den Bergh (1965), this model best fit the data. 
The data from the replacement series were further subjected to analysis proposed by Wit (1960), and the results were interpreted visually using a graph that included the response of the relative production of the shoot dry mass in relation to the proportion, comparing the expected production (hypothesis of non-interaction between the plants) with a obtained yield for both of the species (Harper, 1977; Wit, 1960; Wit \& Van Den Bergh, 1965).

We also calculated the Relative crowding coefficient (RCC) proposed by Wit (1960), which measures the aggressiveness of the two species for each ratio of plants at the adopted critical density, using the following formula: [(DMS tomato plants in coexistence / DMS of slender amaranth plants in coexistence) / (DMS of tomato plants in monoculture / DMS of slender amaranth plants in monoculture)].

\section{Results and Discussion}

Figures A.1 and A.2 present the relative values of the characteristics expressed by the plants at a relative density of 20 plants $\mathrm{m}^{-2}$ measured in the monoculture assays of slender amaranth and tomato. The regression results for the absolute values are provided in Table A.1.

Table A.1. The absolute values of regression analysis for tomato and slender amaranth plants monocultures

\begin{tabular}{|c|c|c|c|}
\hline & Characteristic & Equation & $\mathrm{R}^{2}$ \\
\hline \multirow{10}{*}{ Tomato } & Number of leaves & $y=17.1-0.2 x+0.00123214 x^{2}$ & $96.99 *$ \\
\hline & Number of flowers & $y=3.5-0.1 x+0.00047321 x^{2}$ & $99.38 *$ \\
\hline & Number of fruits & $y=5.8-0.1 x$ & $92.89^{* *}$ \\
\hline & Leaf area $\left(\mathrm{cm}^{2}\right)$ & $y=589.13-4.39 x$ & $90.62 * *$ \\
\hline & Fresh mass fruits (g) & $y=21.5875-0.2231 x$ & $84.79 * *$ \\
\hline & Stem dry mass (g) & $y=7.4950-0.1189 x+0.0007 x^{2}$ & $93.85^{*}$ \\
\hline & Leaf dry mass (g) & $y=4.9000-0.0840 x+0.0005 x^{2}$ & $97.09 * *$ \\
\hline & Inflorescence dry mass $(\mathrm{g})$ & $y=0.0293-0.0007 x+0.00000424 x^{2}$ & $97.39 * *$ \\
\hline & Fruit dry mass (g) & $\mathrm{y}=1.1250-0.01125000 \mathrm{x}$ & $91.01 * *$ \\
\hline & Total dry mass (g) & $y=13.9100-0.2307 x+0.0012 x^{2}$ & $96.46^{*}$ \\
\hline \multirow{7}{*}{ Slender amaranth } & Height $(\mathrm{cm})$ & $y=73.16-0.23 x$ & $86.38 * *$ \\
\hline & Number of leaves & $y=62.9-0.9 x+0.00461607 x^{2}$ & $99.61 * *$ \\
\hline & Leaf area $\left(\mathrm{cm}^{2}\right)$ & $y=563.32-10.650 x+0.06 x^{2}$ & $99.76^{* *}$ \\
\hline & Stem dry mass (g) & $y=7.2603-0.1376 x+0.0007 x^{2}$ & $99.91 * *$ \\
\hline & Inflorescence dry mass $(\mathrm{g})$ & $y=4.6009-0.0903 x+0.0005 x^{2}$ & $96.63 * *$ \\
\hline & Leaf dry mass (g) & $y=2.6021-0.0488 x+0.00028 x^{2}$ & $95.60^{* *}$ \\
\hline & Total dry mass (g) & $y=14.4635-0.2768 x+0.0016 x^{2}$ & $95.50 * *$ \\
\hline
\end{tabular}

$* * \mathrm{P}<0.01 ; * \mathrm{P}<0.05$

The increase in plant density of the slender amaranth plants negatively affected the number of leaves, leaf area, dry mass of the stems, inflorescences, leaves and total mass (Figure A.1 and Table A.1).

Through the regression analysis to the slender amaranth height (Table A.1), it was recorded that the height of amaranth was a less-responsive characteristic, such that when the density increases from 20 to 40 plants $\mathrm{m}^{-2}$, the height was affected by approximately $9 \%$ compared with the calculated value for the density of 20 plants $\mathrm{m}^{-2}$. At the density of 60 plants $\mathrm{m}^{-2}$, the achieved reduction was $13 \%$, and reductions also occurred at 60 plants $\mathrm{m}^{-2}$ but at a lower rate that did not exceed the average value of $24 \%$.

While, the leaves number of slender amaranth recorded $27 \%$ reduction at the density of 40 plants $\mathrm{m}^{-2}$ that calculated by the equation (Table A.1). Moreover, at 40 to 60 plants $\mathrm{m}^{-2}$, the reduction was approximately $45 \%$ of the lower density, whereas the reductions did not exceed the average value of $60 \%$ at the densities exceeding 60 plants $\mathrm{m}^{-2}$.

The leaf area, leaf dry mass and total mass of slender amaranth showed similar sensitivities to the increasing 
plant density, such that the median reduction at the density of 40 plants $\mathrm{m}^{-2}$ was $38 \%$. The reductions were approximately $62 \%$ at the density of 60 plants $\mathrm{m}^{-2}$, and essentially no further reductions were observed with further density increases, with mean values not exceeding $73 \%$.

The inflorescence dry mass and the stem dry mass characteristics were more affected by the intraspecific interaction, with reductions of $40 \%$ in density at 40 plants $\mathrm{m}^{-2}$. At the density of 60 plants $\mathrm{m}^{-2}$, the reductions were approximately $70 \%$ compared with the density of 20 plants. $\mathrm{m}^{-2}$; whilst at 80 plants $\mathrm{m}^{-2}$ the reduction reached values higher than $80 \%$.

The increase in the density of the tomato plants resulted in a decrease in the number of leaves, flowers, fruits, leaf area, fruit fresh mass, dry mass of the stems, leaves, flowers and fruits as well as the total dry mass (Figure A.2 and Table A.1).

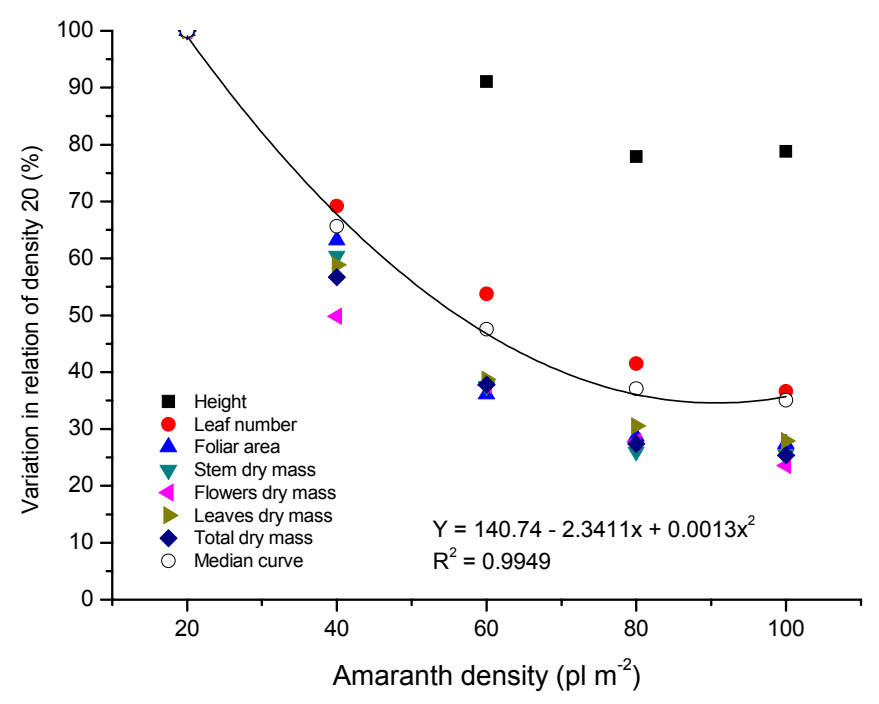

Figure A.1. Variation of slender amaranth (Amaranthus viridis L.) when in coexistence at increasing intraspecific densities relative to the density of 20 plants $\mathrm{m}^{-2}$

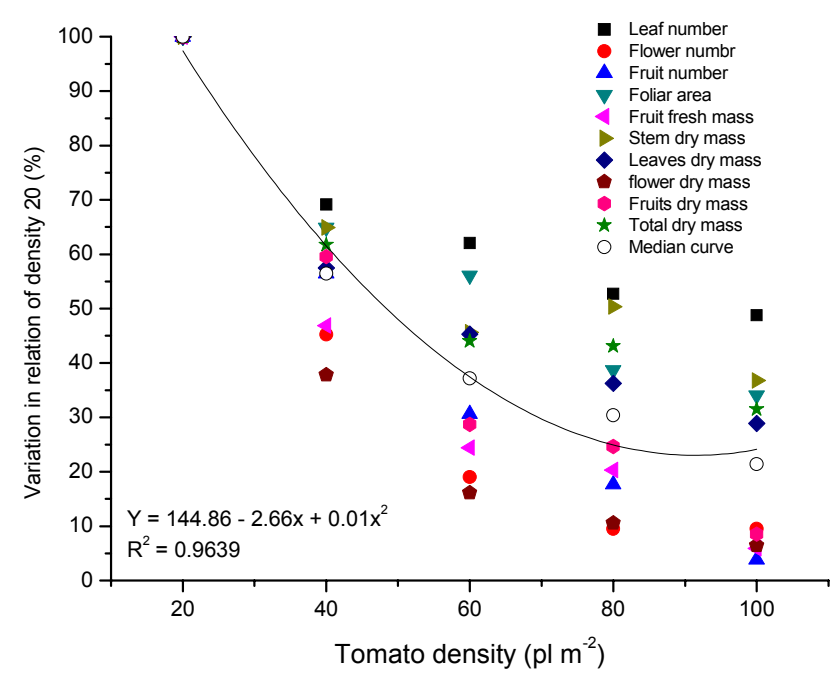

Figure A.2. Variation of tomato (Solanum lycopersicum.) when in coexistence at increasing intraspecific densities relative to the density of 20 plants $\mathrm{m}^{-2}$ 
Regarding the number of leaves for the tomato plants, the reduction in density at 40 plants $\mathrm{m}^{-2}$ was $20 \%$ compared to the calculated value for the density at 20 plants $\mathrm{m}^{-2}$, according to the equation presented in Table A.1. The reductions stabilized at approximately $30 \%$ at the density of 40 plants $\mathrm{m}^{-2}$.

For the stem and leaf dry mass of the tomato plants, decreases at the density of 40 plants $\mathrm{m}^{-2}$ by $30 \%$. For the density of 60 plants $\mathrm{m}^{-2}$, the reductions observed for both of these characteristics did not exceed $50 \%$. The reductions are practically constant at densities of 60 plants $\mathrm{m}^{-2}$, reaching a value not exceeding $60 \%$.

The leaf area was found to be as sensitive to the intraspecific interference as the stem and leaf dry mass, with the reductions increasing from $18 \%$ at the density of 40 plants $\mathrm{m}^{-2}$ to $70 \%$ at the highest density $\left(100\right.$ plants $\left.\mathrm{m}^{-2}\right)$.

The total dry mass of tomato was also sensitive to an increase in the number of plants per area, such that when the density increased from 20 to 40 plants $\mathrm{m}^{-2}$, a reduced of $32 \%$ was recorded. At the density of 60 plants $\mathrm{m}^{-2}$, the calculated reduction was 55\%; above this density, the reduction rate decreased, reaching $70 \%$ at a density of 100 plants $\mathrm{m}^{-2}$.

The number of flowers and fruits, fresh mass of the fruits, and flower and fruit dry masses for tomato were the most sensitive characteristics to intraspecific interference, such that the reductions were less more than $50 \%$ at the densities of 40 and 60 plants $\mathrm{m}^{-2}$. There wasn't significant production, with reductions exceeding $90 \%$ above 60 plants $\mathrm{m}^{-2}$.

By comparatively evaluating the curves in Figures A.1 and A.2, which provide the reductions in the absolute values, the tomato was more sensitive to the competition among individuals than the weed, with a highly numbers of characteristics being affected and the reductions more pronounced.

Moreover, the regression analysis of the reciprocal of the dry matter yield for both species using the reciprocal of the density confirms the higher susceptibility of tomato to intraspecific interference, as demonstrated by the angular coefficients of 0.05 for tomato and 0.04 for slender amaranth (Figure A.3).

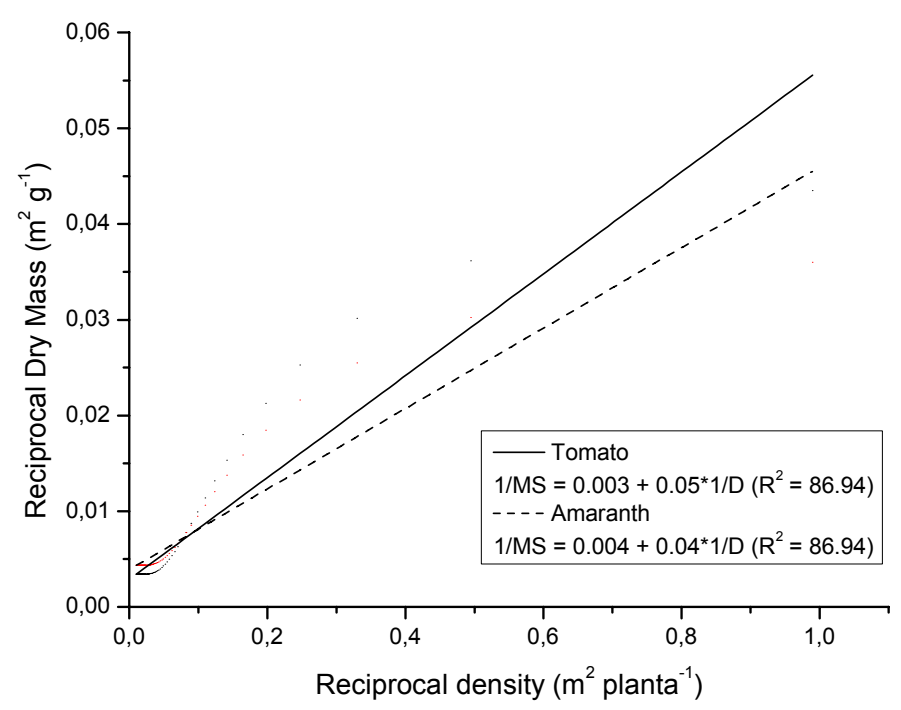

Figure A.3. Responses of tomato and slender amaranth monocultures represented by the reciprocal of the dry matter per area (MS) in relation to the reciprocal of the density

In some studies that evaluated the effect of plant density using cultures of tomato (Hernandez et al., 2002), eucalyptus (Toledo et al., 2001; Dinardo et al., 2003, Costa et al., 2006) and coffee (Dias et al., 2004; Marcolini et al., 2009), the leaves were found to be sensitive to intraspecific competition, responding to a significant increase in the number of plants per $\mathrm{m}^{-2}$. In the present work, the dry mass of the leaves of slender amaranth and tomato were found to be more sensitive to intraspecific competition.

Hernandez et al. (2002) found that weed species were more sensitive to a variation in the density in relation to the stem dry mass than a crop species. The data obtained in the present study confirm those obtained by these 
authors in that $A$. viridis was more sensitive to the increased density of plants. $\mathrm{m}^{-2}$ in relation to the production of stem dry mass.

Evaluating the effect of plant density Lesquerella fendleri, Brahim et al. (1998) observed that an increasing density resulted in a significant decrease in the width, mass and number of branches. Moreover, the increased density of plants of the same species in the area may be beneficial, as observed by Zhang et al. (2012) who reported that the seed yield and seed oil yield of Brassica napus L. were significantly higher with increasing plant density.

On the other hand, the data from the reciprocal of dry mass produced by the population of plants per square meter were subjected to the sigmoidal regression analysis of Boltzman $\left[\mathrm{Y}=(\mathrm{A} 1-\mathrm{A} 2) /\left(1+\mathrm{e}^{\wedge}((\mathrm{x}-\mathrm{x} 0) / \mathrm{dx})\right)+\mathrm{A} 2\right]$, where $\mathrm{A} 1$ indicates the minimal mass production and $\mathrm{A} 2$ indicates the maximum mass production, which is 279.1 g.m $\mathrm{m}^{-2}$ for tomato and 159.6 g.m $\mathrm{m}^{-2}$ for slender amaranth, and $\mathrm{x}$ indicates the density. The maximum theoretical production (Ymax) was determined according to this regression equation, and the population that is reached at the production of $50 \%$ (coefficient $\mathrm{Kn}$ ) is represented by $\mathrm{x} 0$ in the equation. The densities that produce $50 \%$ of the constant final yield were 12.3 plants $\mathrm{m}^{-2}$ for tomato and 12.7 plants $\mathrm{m}^{-2}$ for slender amaranth. Although the differences between the values of Kn were small, due to its lowest value, the results show that tomato was more sensitive to intraspecific interference in comparison to slender amaranth (Figure A.4).

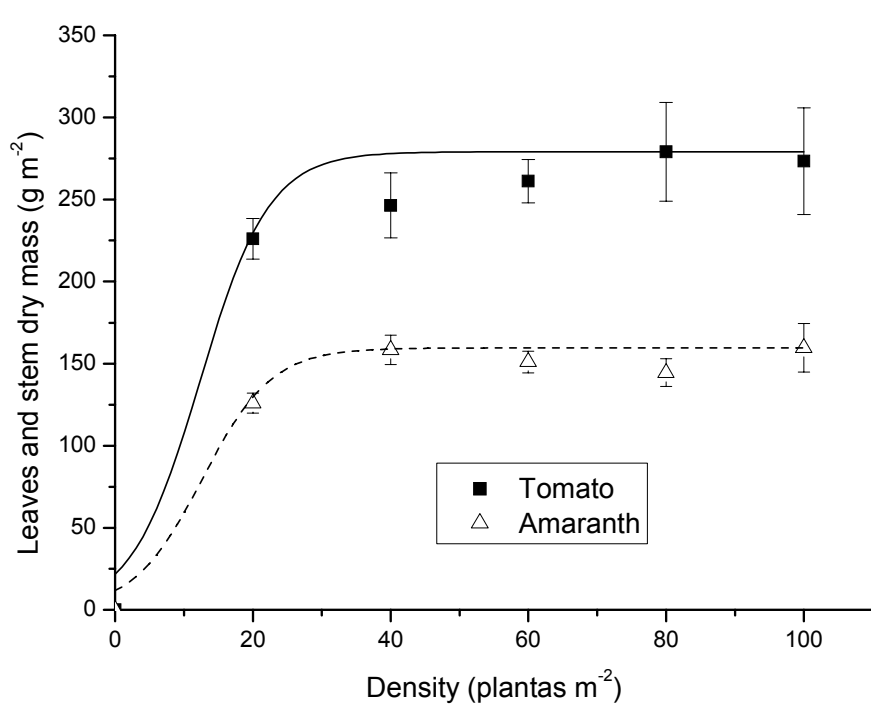

\begin{tabular}{|c|c|c|}
\hline$Y=\frac{A 1-A 2}{1+e^{\frac{x-x 0}{d x}}}+A 2$ & Tomato & $\begin{array}{l}\text { Slender } \\
\text { amaranth }\end{array}$ \\
\hline A1 & 0 & 0 \\
\hline A2 & 279.1 & 159.6 \\
\hline $\mathrm{X} 0$ & 12.3 & 12.7 \\
\hline$d x$ & 5 & 5 \\
\hline $\mathrm{R}^{2}$ & 87.62 & 92.37 \\
\hline
\end{tabular}

Figure A.4. Responses of tomato and slender amaranth monocultures, as represented by the dry matter production of the shoots (leaves + stems) in relation to the density

Our results corroborate those obtained by Christoffoleti and Victoria Filho (1996) who found that a cultivated species (maize) was more sensitive to intraspecific competition and that a weed (Amaranthus retroflexus) was more tolerant to competition among individuals of the same species. However, Yamauti et al. (2011) observed that a cultivated species (triticale) showed a lower sensitivity to intraspecific competition than a weed (turnip). In addition, Carvalho et al. (2010) found that Alexander grass (a weed) was more sensitive to intraspecific competition than wheat plants. 
For tomato and the slender amaranth, the yield obtained at the density of 40 plants $\mathrm{m}^{-2}$ was similar to the maximum productivity (Ymax). However, due to the variability of the tomato data (Figure A.4) and considering that, at a certain plant density, the mass production becomes independent of the density, the "constant final yield law" was adopted at a density of 60 plants $\mathrm{m}^{-2}$, which is the density that most closely matches the constant final productivity. Thus, as the essential requirement of this type of experiment, the experiment was designed at the replacement density of 60 plants $\mathrm{m}^{-2}$ (Jolliffe et al., 1984).

By analyzing the relative crowding coefficient (CRS) proposed by Wit (1960), it is possible to measure the aggressiveness of the two species when they coexist in different proportions using a replacement series. When in coexistence with slender amaranth in the proportion of 75:25 (tomato: slender amaranth) at the density of 60 plants $\mathrm{m}^{-2}$, the tomato plants presented CRS $=2.07$, i.e., was twice as aggressive as the weed. However, when the proportion was changed to $50: 50$ or $25: 75$ at this same density, the tomato aggressiveness was reduced to 1.11 and 1.23 (CRS); yet, the tomato was more aggressive than slender amaranth when in mutual coexistence.

From the results presented in Figure A.5, there is a similarity with the model IIa described by Harper (1977), indicating that the interaction between industrial tomato and slender amaranth occurs by the same environmental resources in which they live but that a species will capture these resources more efficiently than other species. Thus, the tomato was more aggressive and contributed to the total more than expected, whereas slender amaranth contributed less than expected. Therefore, at the density of 60 plants $\mathrm{m}^{-2}$, tomato prefers to coexist with a slender amaranth plant rather than another tomato plant; in other words, the intraspecific interference was more important than the interspecific interference to the cultivated plant. Note that, although the competitive ability of the weed has been more efficient in monoculture, slender amaranth proved to be a less effective competitor when in coexistence with tomato, confirming the results obtained by Christoffoleti and Victoria Filho (1996) and Carvalho and Christoffoleti (2008) that evaluated the interference imposed by species of Amaranthus. In other studies, the cultivated species was also the more aggressive competitor than the weed (Moraes et al., 2009; Passini et al., 2001, Santos et al., 1997; Yamauti et al., 2011). Thus, the competitiveness of weeds may be more related to the high densities in which they occur than to the intrinsic competitive ability of the species.

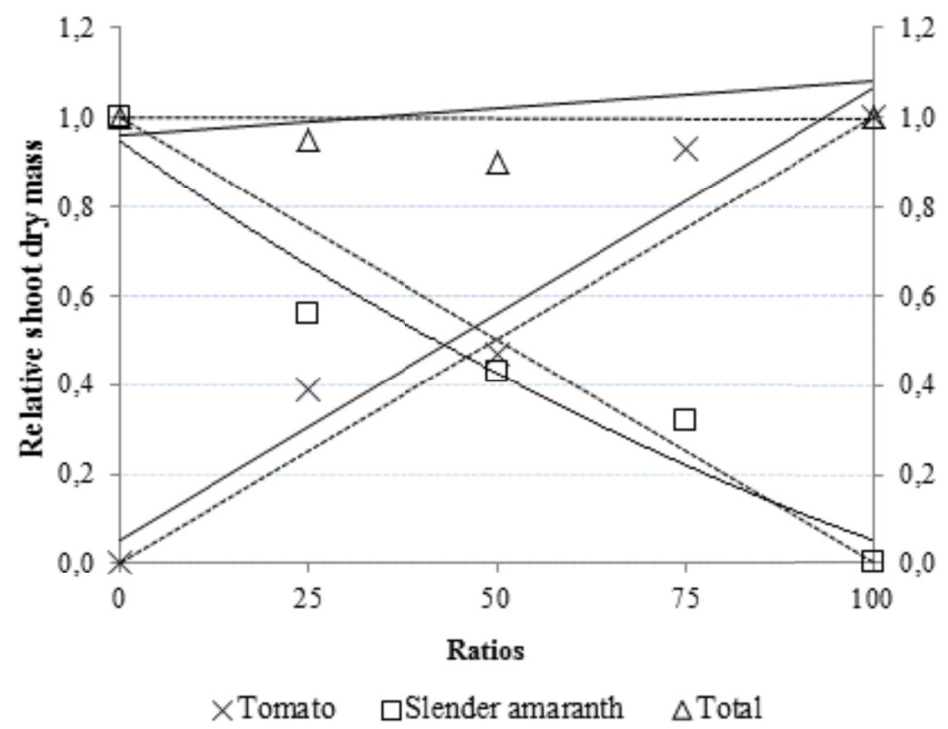

Figure A.5. Relative shoot dry mass of tomato and slender amaranth (Amaranthus viridis) at a fixed total density of 60 plants $\mathrm{m}^{-2}$ (dashed lines represent the no-interaction hypothesis)

Furthermore, it may be that the most critical resource competition has been the light availability for the tomato plants because of its architecture and high-utilization capacity of light, shadowing the slender amaranth plants when in coexistence. The fact that the weed presents $\mathrm{C}_{4}$ photosynthesis and, therefore, requires a higher incidence of light for the production of photoassimilate may have attributed to the competitive advantage of the tomato plants $\left(\mathrm{C}_{3}\right.$ plants $)$, which are more adapted to shaded environments. 


\section{Conclusions}

Tomato exhibited a higher competitive ability for resources than slender amaranth, and the intraspecific competition was more important than interspecific competition for the cultivated plants.

\section{Acknowledgements}

Silva, B. P. and Alves, P. L. C. A. thank Fapesp and CNPq for a research fellowship.

\section{References}

Agrianual. Anuário da agricultura brasileira. (2012). São Paulo: FNP Consultoria (pp. 456-462).

Brahim, K., Ray, D. T., \& Dierig, D. A. (1998). Growth and yield characteristics of Lesquerella fendleri as a function of plant density. Ind. Crops Prod., 9, 63-71. http://dx.doi.org/10.1016/S0926-6690(98)00015-6

Carvalho, L. B., Alves, P. L. C. A., \& Martins, J. V. F. (2010). Effects of plant density and proportion on the interaction between wheat with alexandergrass plants. Bragantia, 70, 40-45. http://dx.doi.org/10.1590/S0006-87052011000100007

Carvalho, S. J. P. De, \& Christofoletti, P. J. (2008). Competition of Amaranthus species with dry bean plants. Scientia Agricola, 65, 239-245. http://dx.doi.org/10.1590/S0103-90162008000300003

Carvalho, S. J. P. De, López-Ovejero, R. F., \& Christofoletti, P. J. (2008). Crescimento e desenvolvimento de cinco espécies de plantas daninhas do gênero Amaranthus. Bragantia, 67, 317-326. http://dx.doi.org/10.1590/S0006-87052008000200007

Christofoletti, P. J., \& Victoria Filho, R. (1996). Efeitos da densidade e proporção de plantas de milho (Zea mays L.) e caruru (Amaranthus retroflexus L.) em competição. Planta Daninha, 14, 42-47. http://dx.doi.org/10.1590/S0100-83581996000100005

Ciampitti, I. A., \& Vyn, T. J. (2011). A comprehensive study of plant density consequences on nitrogen uptake dynamics of maize plants from vegetative to reproductive stages. Field Crop Res., 121, 2-18. http://dx.doi.org/10.1016/j.fcr.2010.10.009

Costa, A. G. F., Alves, P. L. C. A., \& Pavani, M. C. M. D. (2006). Efeito da densidade de plantas de Spermacoce latifolia Aubl. sobre o crescimento inicial de Eucalyptus grandis W. Hill ex. Maiden. Ecossistema (FAZMCG), 29, 39-47.

Dias, G. F. S., Alves, P. L. C. A., \& Dias, T. C. S. (2004). Brachiaria decumbens suppresses the initial growth of Coffea arabica. Scientia Agricola, 61, 563-675. http://dx.doi.org/10.1590/S0103-90162004000600003

Dinardo, W., Toledo, R. E. B., Alves, P. L. C. A., \& Pitelli, R. A. (2003). Efeito da densidade de plantas de Panicum maximum Jacq. sobre o crescimento inicial de Eucalyptus grandis W. Hill ex Maiden. Scientia Forestalis, 64, 59-68.

Dong, H. Z., Kong, X. Q., Li, W. J., Tang, W., \& Zhang, D. M. (2010). Effects of plant density and nitrogen and potassium fertilization on cotton yield and uptake of major nutrients in two fields with varying fertility. Field Crop Res., 119, 106-113. http://dx.doi.org/10.1016/j.fcr.2010.06.019

Harper, J. L. (1977). Population biology of plants. New York: Academic Press.

Hernandez, D. D., Alves, P. L. C. A., \& Salgado, T. P. (2002). Efeito da densidade e proporção de plantas de tomate industrial e de maria-pretinha em competição. Planta Daninha, 20, 229-236. http://dx.doi.org/10.1590/S0100-83582002000200009

Hernandez, D. D., Alves, P. L. C. A., Pavani, M. C. M. D., \& Parreira, M. C. (2007). Períodos de interferência de maria-pretinha sobre tomateiro industrial. Horticultura Brasileira, 25, 199-204. http://dx.doi.org/10.1590/S0102-05362007000200014

Hiltbrunner, J., Streit, B., \& Liedgens, M. (2007). Are seeding densities an opportunity to increase grain yield of winter wheat in a living mulch of white clover? Field Crop Res., 102, 163-171.

Jolliffe, P. A., Ninjas, A. N., \& Runeckles, V. C. (1984). A reinterpretation of yield relationships in replacement series experiments. Journal of Applied Ecology, 21, 227-243.

López-Bellido, F. J., López-Bellido, L., \& López-Bellido, R. J. (2005). Competition, growth and yield of faba bean (Vicia faba L.). Eur. J. Agron., 23, 359-378. http://dx.doi.org/10.1016/j.eja.2005.02.002 
Marcolini, L. W., Alves, P. L. C. A., Dias, T. C. S., \& Parreira, M. C. (2009). Effect of the density and of the distance of Brachiaria decumbens Satff on the initial growth of Coffea arabica L. seedligns. Coffee Science, 4, 11-15.

Moraes, P. V. D., Agostinetto, D., Galon, L., \& Rigole, R. P. (2009). Competitividade relativa de soja com arroz-vermelho. Planta Daninha, 27, 35-40. http://dx.doi.org/10.1590/S0100-83582009000100006

Nascente, A. S., Pereira, W., \& Medeiros, M. A. (2004). Interferência das plantas daninhas na cultura do tomate $\begin{array}{llll}\text { para } & \text { Hocessamento. } & \text { 6ricultura }\end{array}$ http://dx.doi.org/10.1590/S0102-05362004000300020

Passini, T., Christofoletti, P. J., \& Yada, I. F. U. (2003). Competitivity of the common-bean plant relative to the weed alexandergrass [Brachiaria plantaginea (Link) Hitch.]. Scientia Agricola, 60, 259-268. http://dx.doi.org/10.1590/S0103-90162003000200009

Pitelli, R. A., \& Karam, D. (1998). Ecologia das plantas daninhas e sua interferência em culturas florestais. In Seminário sobre Plantas Daninhas e o Uso de Herbicidas em Reflorestamento, 44-63.

Radosevich, S. R. (1987). Methods to study interactions among crops and weeds. Weed Technol., 1, 190-198.

Santos, M. B., Bewick, T. A., Stall, W. M., \& Shilling, D. G. (1977). Competitive interactions of tomato (Lycopersicon esculentum) and nutsedges (Cyperus spp.). Weed Science, 45, 229-233.

Silva, B. P., Carvalho, L. B., Alves, P. L. C. A., Souza, M. C., \& Magário, F. B. (2010). Interferência de caruru-de-mancha, maria-pretinha, picão-preto e tiririca em tomateiro industrial. Bragantia, 69, 313-318. http://dx.doi.org/10.1590/S0006-87052010000200008

Toledo, R. E. B., Dinardo, W., Bezutte, A. J., Alves, P. L. C. A., \& Pitelli, R. A. (2001). Efeito da densidade de plantas de Brachiaria decumbens Stapf sobre o crescimento inicial de mudas de Eucalyptus grandis W. Hill ex Maiden. Scientia Forestalis, 60, 109-117.

Wit, C. T. (1960). On competition. Verslagen Landbouw Onderzoek, 66, 1-82.

Wit, C. T., Van den, \& Bergh, J. P. (1965). Competition between herbage plants. Neth. J. Agric. Sci., 13, 212-221.

Yamauti, M. S., Alves, P. L. C. A., \& Carvalho, L. B. (2011). Interações competitivas de triticale (Triticum turgidosecale) e nabiça (Rhaphanus raphanistrum) em função da população e proporção de plantas. Planta Daninha, 29, 129-135. http://dx.doi.org/10.1590/S0100-83582011000100015

Zhang, S., Liao, X., Zhang, C., \& Xu, H. (2012). Influences of plant density on the seed and oil content of winter oilseed rape (Brassica napus L.). Ind. Crops Prod., 40, 27-32. http://dx.doi.org/10.1016/j.indcrop.2012.02.016 